\title{
REPRODUCTION OF Leishmania (Leishmania) infantum chagasi IN CONDITIONED CELL CULTURE GROWTH MEDIUM
}

Yeda L. NOGUEIRA \& Eunice A.B. GALATI

\section{SUMMARY}

Leishmanias can be produced by inoculation in conditioned McCoy cell culture growth medium (CGM). Leishmania (Leishmania) infantum chagasi (100 parasites) grown in NNN medium was inoculated in $2.5 \mathrm{~mL}$ CGM, kept in plates (24 wells) and its multiplication was observed for five days (120 hours). After day 5, the medium was saturated with the flagellate forms of the parasite (promastigotes). The reproduction of the leishmanias was observed every 24 hours and the number of parasites was calculated by counting the parasites in a drop of $10 \mu \mathrm{L}$ and photomicrographied. So the number of Leishmanias was adjusted to $1 \mathrm{~mL}$ volume.

The advantage of the technique by isolation of Leishmania in CGM demonstrated in this study is its low cost and high efficacy even with a small quantity of parasites $\left(10^{2}\right.$ promastigotes) used as inoculum. Additionally, isolation of the leishmania can be obtained together with an increase in their density (180 times) as observed by growth kinetics, within a shorter time.

These results justify the use of this low-cost technique for the isolation and investigation of the behavior and multiplication of Leishmania both in vertebrates and invertebrates, besides offering means of obtaining antigens, whether whole antigens (leishmanias) or the soluble antigens produced by the parasites which may be useful for the production of new diagnostic kits.

KEYWORDS: Leishmania (Leishmania) infantum chagasi; Flagellate form; Growth; McCoy Cell Lineage.

\section{INTRODUCTION}

Leishmania (Leishmania) infantum chagasi is the main aetiological agent of visceral leishmaniasis (VL) which, although endemic in many Brazilian states, is considered to be a re-emergent disease since it is currently affecting not only the canine population of rural areas but also that of major urban centers. Due to the continental dimensions of the Country there are various environmental and migratory factors that have contributed to the presence of this zoonosis and the fact that it has become a serious Public Health problem ${ }^{1,2}$.

The phlebotomine Lutzomyia longipalpis is the main vector of Leishmania (Leishmania) infantum chagasi in Brazil where it infects $\operatorname{dog} s^{12}$, making them a reservoir and potential link in the transmission chain of the parasite to humans ${ }^{13}$. Migration of human populations from rural areas into the outskirts of major urban centers has favored the adaptation of this phlebotomine to peridomiciliary and intradomiciliary environments, since the new housing for the migrants tends to be built in areas of recently cleared forest or close to woodland ${ }^{11}$. Furthermore, many of these migrants, originating in endemic areas, bring their domestic dogs, which may be reservoirs of the parasite, with them. These, domestic reservoirs, in presence of the vector and other, non-domestic, reservoirs, complete the epidemiological picture of VL.

Visceral leishmaniasis is usually diagnosed with a light microscope to detect the parasites in aspirates of lymph nodes, bone marrow, skin or the spleen (postmortem $)^{7}$. The monitoring of the endemic areas in Brazil is undertaken by serological testing using the indirect immunofluorescence reaction (IIFR) ${ }^{4}$ or ELISA (enzyme-linked immunosorbent assay $)^{21}$. These techniques do not offer a satisfactory means of identifying the disease, since positive serology only indicates circulation of the agent in human populations or of reservoirs in a certain area. Such tests operate, respectively, with sensitivity and specificity values of $80 \%$ and $100 \%$. They may further present a crossreaction with infections caused by other agents and especially other Trypanosomatidae ${ }^{22}$. The parasitologic laboratory test that identifies the parasite in aspirates (whether from bone marrow, lymph node, blood or skin specimens) is not always practicable, because it requires a specialized technical team and resources that are not everywhere available. Similarly, isolation of Leishmania (Leishmania) infantum

Departamento de Epidemiologia, Faculdade de Saúde Pública, Universidade de São Paulo, São Paulo, SP, Brasil.

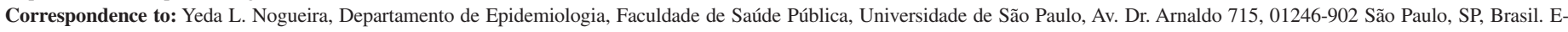
mail: ynogueir@usp.br 
chagasi using laboratory animals, such as hamsters ${ }^{9}$, is a very slow and costly method.

Several techniques have been described to obtain isolations in vitro, including: cultivation on semi-solid Novy-McNeal-Nicolle medium $(\mathrm{NNN})^{15}$, on RPMI-1640 medium ${ }^{13}$ or on Schneider medium enriched with urine ${ }^{14}$, but all fail to perpetuate leishmanias after several passages, thereby limiting large-scale production.

Due to the prevalence of the disease and its re-emergence in urban centers, there is a need to develop effective methods to make isolation of Leishmania (Leishmania) infantum chagasi, as well as its perpetuation for the production of antigens to be used in diagnostic kits possible. Furthermore, these kits should be improved so that they become specific for Leishmania (Leishmania) infantum chagasi and thereby avoid cross-reactions with other Trypanosomatidae ${ }^{22}$.

In this work the growth of Leishmania (Leishmania) infantum chagasi during several passages in conditioned McCoy cell culture growth medium is described.

\section{MATERIAL AND METHODS}

Promastigotes strain: promastigote forms of Leishmania (Leishmania) infantum chagasi were cultivated in semi-solid NovyMcNeal-Nicolle medium (NNN medium). The strain (MCAN/BR/ 2002/LVV-136) used in the present work was originally isolated from a dog from Campo Grande and identified by the Instituto Oswaldo Cruz. It is registered in their strain bank as L 2665.

Conditioned growth medium (CGM): Eagle's medium supplemmented with 5\% foetal calf serum (FCS) used for the growth McCoy cells ${ }^{17}$. After the cells' growth the medium having the excretion of metabolites is considered "conditioned".

Passages in conditioned growth medium: Promatigotes grown in NNN medium were inoculated in conditioned medium. The inoculum was a $10 \mu \mathrm{L}$ harvest from a solution with $10^{4}$ parasites $/ \mathrm{mL}$ and kept in $2.5 \mathrm{~mL}$ CGM (24 wells tissue culture plates) and its multiplication was observed for five days (120 hours). After day 5, the medium was saturated with the flagellate forms of the parasite (promastigotes). Soon afterwards, successive passages were made by inoculating aliquots with $2 \times 10^{4}$ promastigotes $/ \mathrm{mL}(25 \mathrm{~mL})$ plus $(25 \mathrm{~mL})$ of conditioned growth medium in $100 \mathrm{~cm}^{3}$ bottles at room temperature $\left(25-27^{\circ} \mathrm{C}\right)$.

Growth kinetics: The reproduction of the leishmanias was observed every 24 hours and the number of parasites in $10 \mu \mathrm{L}$ of inoculated fluid was counted by fixing each microsope field and photomicrography undertaken. Thus the average number of parasites was calculated and the concentration adjusted to the final volume of $1 \mathrm{~mL}$.

\section{RESULTS}

Figure 1A shows the Leishmania density obtained after the $5^{\text {th }}$ day (120 hours) in conditioned growth medium after the culture of McCoy cells, observed under a microscope; Fig. 1B shows one Leishmania at the moment of cell division and Fig. 1C a group of Leishmania in the typical of the growth formation.
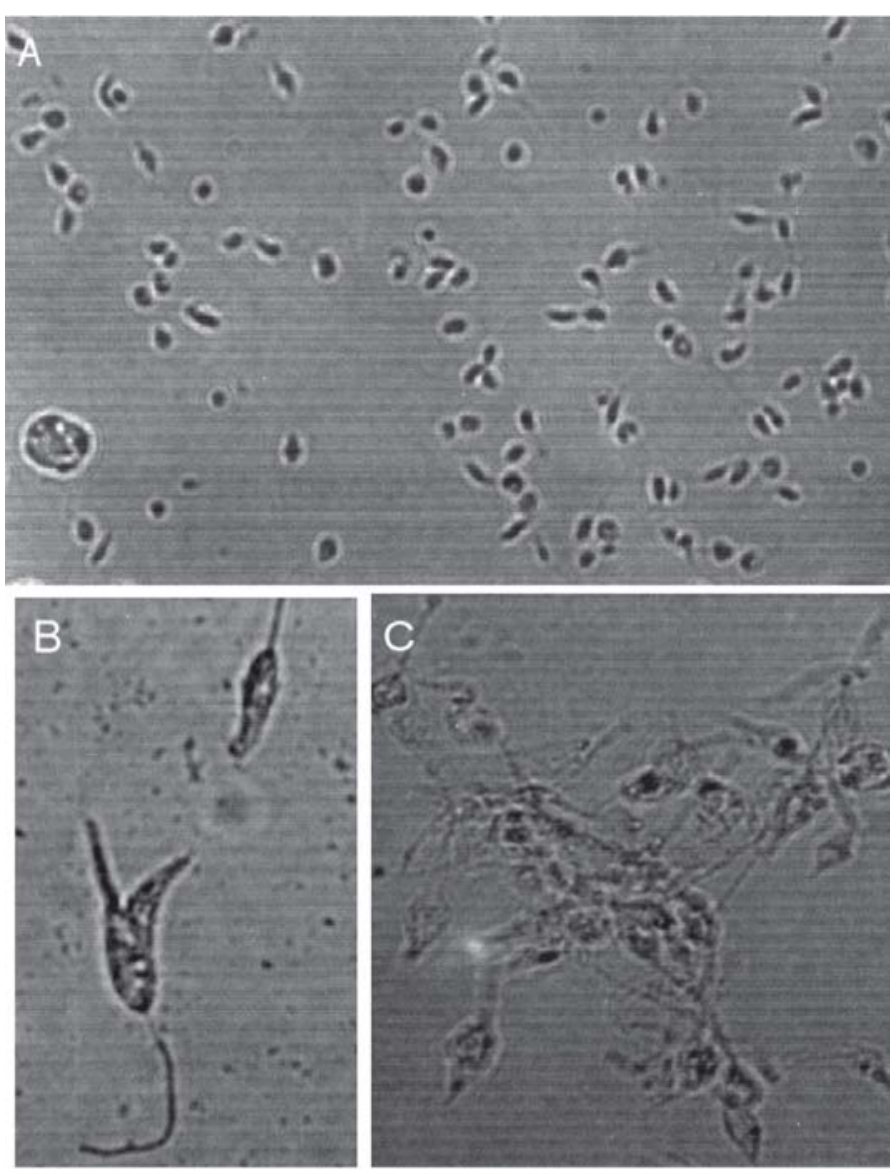

Fig. 1 - Leishmania (Leishmania) infantum chagasi (promastigotes) grown in conditioned McCoy cell culture growth medium. (A) Leishmania density after the $5^{\text {th }}$ day (120 hours) observed under light microscope (400X magnification); (B) the reproduction of one Leishmania (1000X magnification) and (C) Group of Leishmania, typical formation observed during growth. (1000X magnification).

Figure 2 demonstrates the growth kinetics of these parasites over a 5-day period (120 hours) and shows that the Leishmania increases at geometric progression: $10^{2} / \mathrm{mL}$ (24 hours); $10^{3} / \mathrm{mL}$ (48 hours); $2.3 \mathrm{x}$ $10^{3} / \mathrm{mL}$ ( 72 hours) and $4.6 \times 10^{3} / \mathrm{mL}$ until the $4^{\text {th }}$ day (96 hours), so an exponential growth of Leishmania number ocurred between the $4^{\text {th }}$ and $5^{\text {th }}$ day (120 hours), finally attained the load of $1.8 \times 10^{4}$ parasites $/ \mathrm{mL}$.

\section{DISCUSSION}

Visceral Leishmaniasis is a zoonosis of which dogs are the main reservoir ${ }^{2}$. The control strategy of Brazilian epidemiological surveillance in endemic areas is to use positive serology results to eliminate dogs that present a potential risk for transmission of leishmaniasis ${ }^{2,4}$.

This criterion, however, is considered very controversial, since serology is an indirect method, which may give false-positive results ${ }^{6}$. Further, $60 \%$ of serologically positive dogs present spontaneous cure and only 2 to $3 \%$ of these dogs actually develop the disease ${ }^{11}$. Most of 


\section{growth kinetics of the promastigotes}

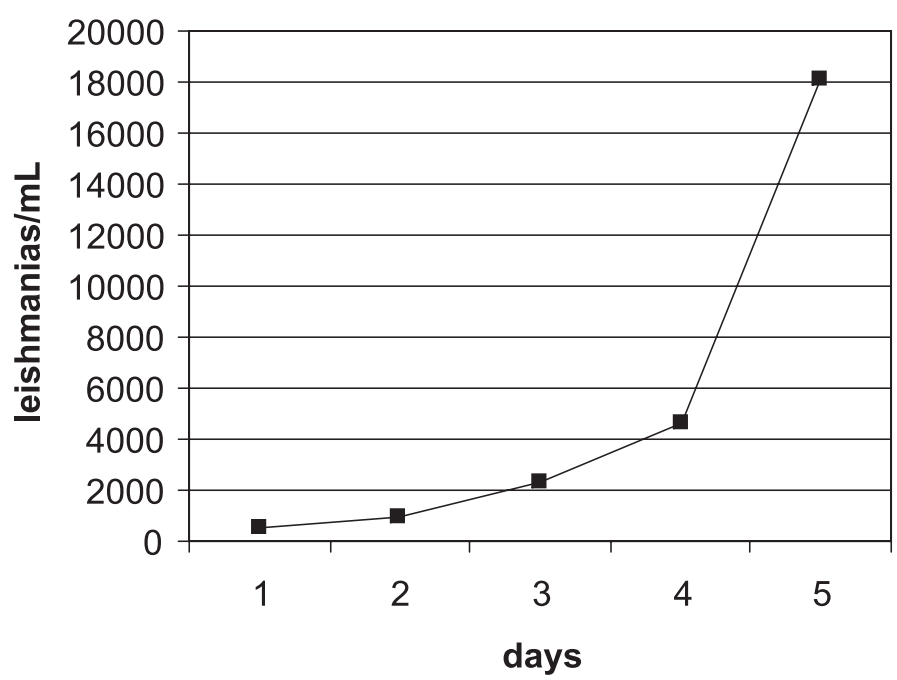

Fig. 2 - Growth kinetics of the promastigotes grown in conditioned cell culture growth medium. Number of promastigotes $/ \mathrm{mL}$ observed over a five-day period under a light microscope at $400 \mathrm{X}$ magnification.

the dogs, even when infected, are asymptomatic or have the disease in the latent or subclinical form ${ }^{10,11}$. Consequently, it is a highly questionable procedure to sacrifice pet dogs solely on the basis of a serologic diagnosis.

In addition, parasitological diagnosis, i.e. testing for Leishmania in the aspirate of bone marrow, lymph nodes, blood or skin, is an invasive method ${ }^{5}$ that calls for specialist knowledge and thus is not practicable when there is a high demand for these exams. To resolve this dilemma, the PCR technique offers a solution by means of specific primers that make identification of the various Leishmania species possible ${ }^{19,20,22}$. Another advantage of this technique is that it requires low parasite density, i.e. a minimum level of $10^{3}$ parasites $/ \mathrm{mL}^{20}$. This same author has reported that given the high sensitivity of the test, it is possible to perform PCR with just 10 parasites and to detect the band in the electrophoresis gel. Nevertheless, PCR does not always detect the parasite, since inhibition of the reaction may occur in some types of sample ${ }^{3}$, presenting a decrease in the sensitivity of the test to $60 \%$ $70 \%$. Nevertheless, this is one of the most promising techniques for the identification of the parasite, given the fact that it is noninvasive and the circulating parasites can be detected in a sample of blood or leukocyte cream.

The advantage of the technique by isolation of Leishmania in conditioned cell culture growth medium demonstrated in this work is its low cost and high efficacy even with a small quantity of parasites (100 promastigotes as inoculum). Additionally, isolation of the leishmania can be obtained together with an increase in their density within a shorter time, as may be seen in the growth kinetics (Fig. 2), especially when compared with the method of isolation in laboratory rodents which takes about six months to achieve a critical mass of leishmanias (in amastigote form) ${ }^{9}$, so as to permit their isolation in
NNN or RPMI medium and thus obtain the flagellate form (promastigote).

The technique proposed here, besides its low cost due to the conditioned growth medium would be discarded (in contrast with the high costs incurred by direct isolation in various culture mediums) does not require sophisticated equipment or highly specialized technical personnel. Aseptic care alone is sufficient for inoculating the collected material into tubes containing growth culture medium and antibiotics, at room temperature, ready to forward to any laboratory capable of identifying the parasites. Thus, this technique can be carried out without difficulty under Brazilian field conditions and the material can be transported to great distances. Consequently, it is a very appropriate method for collecting the various strains of parasites. This could dramatically increase the efficacy and quality of epidemiologic fieldwork. The method will also enable follow up of clinical, subclinical and asymptomatic cases in order to provide more information about the course of the disease, as well as to accompany the reduction of parasitemia during chemotherapy treatment.

Yet another benefit offered by the technique of obtaining promastigotes grown in conditioned medium is the large-scale production of the specific antigen against a specific Leishmania for the production of new diagnostic kits for serologic tests ${ }^{16}$. This is because in the conditioned medium, not only the promastigotes serve as antigens, but the parasites liberate soluble immunogenic antigens that are also recognized by sera of dogs, which have been infected by Leishmania.

In conclusion, the above results justify the use of this low-cost technique to isolate and investigate the behavior and multiplication of Leishmania in vertebrates and invertebrates, besides offering means of obtaining whole antigens (Leishmania) or soluble antigens produced by the parasites.

\section{RESUMO}

Isolamento e crescimento de Leishmania (Leishmania) infantum chagasi em meio de crescimento condicionado de cultura celular

Leishmânias podem ser produzidas em meio de crescimento condicionado, após o cultivo de células McCoy (MCC). Promastigotas crescidas em meio semi-sólido NNN foram inoculadas em MCC, inicialmente, 100 parasitos por poço com 2,5 mL de McCoyMCC, em placas com 24 poços, sua multiplicação foi observada por uma cinética de 120 horas. Após este tempo, o meio estava saturado de promastigotas. A reprodução das leishmânias foi acompanhada a cada 24 horas, com contagem do número de parasitos por campo fotomicrografado.

Como vantagem da técnica do crescimento da leishmânia em MCC tem-se o seu baixo custo, com pequena quantidade de parasitos podese obter o aumento da densidade de promastigotas em tempo reduzido.

Com o emprego dessa técnica pode-se estudar o comportamento e a multiplicação das leishmânias nos vertebrados e invertebrados, assim como, obter antígenos, tanto brutos (leishmânia) como solúveis, produzidos pelos parasitos, que poderão ser úteis para se desenvolver kits de diagnósticos. 


\section{ACKNOWLEDGEMENTS}

We are grateful to Maria Elizabeth Carvalheiro Dorval, Universidade Federal de Mato Grosso do Sul, who donated the Leishmania (Leishmania) infantum chagasi strain isolated from a dog in Mato Grosso do Sul state and to M Dulce Bianchi Rosa for technical assistance, Tropical Diseases Laboratory - Epidemiology Department of Faculdade de Saúde Pública/USP.

\section{REFERENCES}

1. ALVAR, J.; CAÑAVATE, C.; GUTIÉRREZ-SOLAR B. et al. - Leishmania and human immunodeficiency virus coinfection; the first 10 years. Clin. Microbiol. Rev., 10: 298-319, 1997.

2. ARIAS, J.R.; MONTEIRO, P.S. \& ZICKER, F. - The reemergence of visceral leishmaniasis in Brazil. Emerg. infect. Dis., 2: 145-146, 1996.

3. ASHFORD, D.A.; BOZZA, M.; FREIRE, M. et al. - Comparison of the polymerase chain reaction and serology for detection of canine visceral leishmaniasis. Amer. J. trop. Med. Hyg., 53: 251-255, 1995.

4. BADARÓ, R.; REED, S.G. \& CARVALHO, E.M. - Immunofluorescent antibody test in American visceral leishmaniasis, sensitivity and specificity of different morphological forms of two leishmania species. Amer. J. trop. Med Hyg., 32: 480-484, 1983.

5. BARRECA, G.S.; MATERA, G.; DE MAJO, M. et al. - Early detection of Leishmania promastigotes in dog bone marrow cultures by acridine orange stain. Diagn. Microbiol. infect. Dis., 37: 247-251, 2000

6. COURTNAY, O.; QUINNELL, R.J.; GARCEZ, L.; SHAW, J.J. \& DYE, C. - Infectiousness in a cohort of Brazilian dogs: why culling to control of visceral leishmaniasis in areas of high transmission. J. infect. Dis., 186: 1314-1328, 2002.

7. COWELL, R.L. \& TYLLER, R.D. - Diagnostic cytology of the dog and cat. 3. ed. Santa Barbara, American Veterinary Publications, 1989.

8. CUNHA, S.; FREIRE, M.; EULALIO, C. et al. - Visceral leishmaniases in a new ecological niche near major metropolitan area in Brazil. Trans. roy. Soc. trop. Med. Hyg., 89: 155-158, 1995.

9. DUARTE, M.I.S.; LAURENTI, M.D.; ANDRADE JR., H.F. \& CORBETT, C.E.P. Comparative study of the biological behaviour in hamsters of two isolates of Leishmania characterized respectively as $L$. major-like and $L$. donovani. Rev. Inst. Med. trop. S. Paulo, 30: 21-27, 1988.

10. DYE, C.; VIDOR, E. \& DEREURE, J. - Serological diagnosis of leishmaniasis: detecting infection as well as disease. Epidem. Infect., 110: 647-656, 1993.
11. GENARO, A.C. - Leishmaniose visceral americana. In: NEVES, D.P. Parasitologia humana. 10. ed. Rio de Janeiro, Atheneu, 2000. p. 56-72.

12. LAINSON, R. \& RANGEL, E.F. - Flebotomíneos do Brasil. Rio de Janeiro, Fiocruz, 2003 .

13. LAINSON, R. \& SHAW, J.J. - Epidemiology and ecology of leishmaniases in Latin America. Nature, 273: 595-600, 1978

14. LIMA, H.C.; BLEYENBERG, J.A. \& TITUS, R.G. - A simple method for quantifying Leishmania in tissues of infected animals. Parasit. today, 13: 80-82. 1997.

15. LIMONCU, M.E.; BALCIOGLU, C.; YERELI, K.; OZBEL, Y. \& OZBILGIN, A. - A new experimental in vitro culture medium for cultivation of Leishmania species. J. clin. Microbiol., 35: 2430-2431, 1997.

16. MARTIN, S.K.; THUITA-HARUN, L.; ADOYO-ADOYO, M. \& WASUNNA, K.M. - A diagnostic ELISA for visceral leishmaniasis based on antigen from media conditioned by Leishmania donovani promastigotes. Ann. trop. Med. Parasit., 92: 571-577, 1998.

17. McCoY cell line. http://www.biotech.ist.unige.it/cldb/cat1.html [accessed 13/06/2005] and http://www.atcc.org catalog number= CRL 1696 [accessed 13/06/2005].

18. MERLEN, T.; SERENO, D.; BRAJON, N.; ROSTAND, F. \& LEMESRE, J.L. Leishmania spp.: completely defined medium without serum and macromolecules (CDM/LP) in vitro cultivation of infective promastigote form. Amer. J. trop. Med. Hyg., 60: 41-50, 1999.

19. SAVANI, E.S.M.M.; DE OLIVEIRA CAMARGO, M.C.; CARVALHO, M.R. et al. - The first record in the Americas of an autochthonous case of Leishmania (Leishmania) infantum chagasi in a domestic cat (Felix catus) from Cotia County, São Paulo State, Brazil. Vet. Parasit., 120: 229-233, 2004.

20. ULIANA, S.R.R.; NELSON, K.; BEVERLEY, S.M.; CAMARGO, E.P. \& FLOETERWINTER, L.M. - Discrimination amongst leishmania by polymerase chain reaction and hybridization with small subunit ribosomal DNA derived nucleotides oligonucleotides. J. euk. Microbiol., 41: 324-330, 1994.

21. VOLLER, A.; BIDWELL, D.E. \& BARTLETT, A. - Enzyme immunoabsorbent assay. In: ROSE, N. \& FRIEDMAN, H., ed. Manual of clinical Immunology. Washington, American Society of Microbiology, 1980. p. 359-371.

22. WEISS, J.B. - DNA probes and PCR for diagnosis of parasitic infections. Clin. Microbiol. Rev., 8: 113-130, 1995.

Received: 31 August 2005 Accepted: 6 March 2006 